\title{
CONSOLIDAÇÃO DO ATO REVOGÁVEL VIS À VIS A DECADÊNCIA DO DIREITO DE PROPOSITURA DA AÇÃO REVOCATÓRIA
}

\author{
Oksandro Osdival Gonçalves* \\ Thalita Almeida Salles*
}

\section{RESUMO}

$\mathrm{O}$ artigo trata da inexistência de limitação temporal para revocação de atos praticados em prejuízo da massa falida e credores, nos termos do artigo 130 da Lei 11.101/2005. O objetivo é de analisar referido dispositivo admitindo as hipóteses de omissão do legislador que não fixou termo para revocação do ato fraudulento ou, em sentido oposto, assumir que é eloquente o silêncio do legislador com objetivo de evitar convalidação de negócios jurídicos fraudulentos. O método utilizado foi o dedutivo e a pesquisa bibliográfica também se apoiou no estudo de casos julgados pelo Superior Tribunal de Justiça e Tribunais de Justiça estaduais.

PALAVRAS-CHAVE: Negócio Jurídico; Falência; Ação Revocatória; Artigo 130 da Lei no 11.101/2005; Decadência.

\section{CONSOLIDATION OF REVOKABLE ACT IN VIEW OF THE EXPIRATION OF THE RIGHT OF BRINGING REVOCATORY SUIT}

\begin{abstract}
The article deals with the lack of temporal limitation for revoking fraudulent acts performed to the loss of bankrupt estate and its creditors, as per article 130, Law\#11101/2005. The purpose comprises analyzing such legal text, admitting the assumptions of legislator's fault when omitting a fixed term to revoking fraudulent acts or, in a different point of view, assume that legislator's silence is eloquent aiming to avoid consolidation of fraudulent legal business. Deductive method was adopted, and bibliographic research also leaned in the study of cases judged by the Higher Court of Justice and by Brazilian Courts of Justice.
\end{abstract}

KEY-WORDS: Legal Business; Bankruptcy; Revocatory Suit; Article 130 of Law n. 11,101/2005; Expiration.

\section{INTRODUÇÃO}

\footnotetext{
* Professor do Programa de Pós-Graduação em Direito (Mestrado/Doutorado) da Pontifícia Universidade Católica do Paraná. Professor titular de Direito Comercial da Escola de Direito da Pontifícia Universidade Católica do Paraná. Membro do Conselho Editorial da Editora Fórum. Coordenador da Revista de Direito Empresarial. Pós-Doutor em Direito pela Faculdade de Direito da Universidade de Lisboa. Doutor em Direito Comercial - Direito das Relações Sociais pela Pontifícia Universidade Católica de São Paulo. Mestre em Direito Econômico pela Pontifícia Universidade Católica do Paraná; oksandro@ oksandro.adv.br.

* Advogada e Consultora nas áreas de Direito Empresarial, Contencioso Cível, e Contratos; Sócia do escritório Bastos-Tigre, Coelho da Rocha, Lopes e Freitas Advogados, cursando o mestrado em Direito Empresarial pela UERJ; thalita.almeida@bastostigre.adv.br
} 
O objeto da ação revocatória é declarar a ineficácia relativa do ato cometido em fraude e prejuízo de credores submetidos a procedimento falimentar. Assim, o artigo trata da inexistência de limitação temporal para revocação de atos praticados em prejuízo da massa falida e credores, em face do decurso do prazo decadencial computado para o fim de ajuizamento de ação revocatória prevista no art. 130 da Lei n. 11.101/2005 (LRE).

A relevância do tema é sustentada pela premente necessidade de conhecer adequadamente a ferramenta que se presta a restituir à massa falida os ativos transferidos ou cedidos em fraude. Essa importância fica reforçada no atual cenário em que cresce o número de procedimentos falimentares ${ }^{1}$, em razão do alto índice de recuperações judiciais malsucedidas.

Para enfrentar o tema proposto, o artigo promoverá a análise do texto legal, de modo a conferir adequada interpretação da intenção do legislador que não fixou prazo limite para convalidação do ato, cuja eficácia será relativizada em relação à massa falida quando do (eventual) julgamento procedente da ação revocatória.

As hipóteses estão fundadas nas seguintes premissas: o fato de o legislador não ter indicado prazo específico para consolidação do ato que se pretender revogar, revela uma omissão do texto legal que precisa de solução conferida judicialmente, nos termos do art. $4^{\text {o2 }}$ do Decreto Lei n. 4.657/1942. A segunda premissa se funda no raciocínio de que o silêncio do legislador, em relação à consolidação do ato que se pretender revogar, não é resultado de lacuna legal, mas de silêncio eloquente e proposital para que não haja termo fixado que garanta a estabilização de negócios jurídicos fundados na pretensão de fraudar credores.

O método utilizado foi o dedutivo e a pesquisa bibliográfica também se apoiou no estudo de casos julgados pelo Superior Tribunal de Justiça, bem como por Tribunal de Justiça Estadual.

No primeiro capítulo trata-se do sistema de invalidades do negócio jurídico antes da decretação da quebra, quando ainda é cabível a ação pauliana do direito civil, a qual busca obter anulação dos atos cometidos em fraude contra credores e, depois da decretação da quebra, quando é cabível ajuizamento de ação revocatória, que persegue a declaração de ineficácia do ato cometido em fraude e prejuízo da massa e dos credores. Na sequência, foram

\footnotetext{
${ }^{1}$ Segundo análise de Eduardo Coube de Carvalho (2019), veiculada pelo JOTA, a cada dez pedidos de recuperação judicial, somente três alcançam a homologação do plano de recuperação judicial, com a consequente concessão da medida.

${ }^{2}$ Art. $4^{\underline{0}}$ Quando a lei for omissa, o juiz decidirá o caso de acordo com a analogia, os costumes e os princípios gerais de direito.
} 
abordados os aspectos processuais da revocatória, marcadamente o prazo decadencial que fulmina o exercício desse direito. No capítulo seguinte, tratou-se dos aspectos históricos da ação revocatória, com menção à aplicação subsidiária da legislação civil para interpretação do art. 130 da lei falimentar vigente. Na última parte, foram analisados alguns precedentes judiciais que indicam posicionamento do judiciário quanto à irrelevância do momento em que se praticou o ato cuja eficácia poderá ser questionada em sede de ação revocatória.

Embora seja dissidente a doutrina sobre o tema, a conclusão do estudo ora proposto é de que a omissão do legislador em relação à limitação temporal para declaração de ineficácia relativa é eloquente e proposital, em razão das consequências nefastas impostas à massa falida e aos credores prejudicados pela consolidação de negócio jurídico fraudulento, apenas em razão do decurso do tempo.

\section{SISTEMA DE INVALIDADES NA LEI DE FALÊNCIA:}

O tratamento conferido pelo direito comercial brasileiro em relação à fraude evoluiu do sistema de nulidades - previsto no Código Comercial de 1850 , no seu art. $828^{3}$ - para o sistema de ineficácias com a promulgação da Lei n. 2.024, de 1908, por meio dos artigos $55^{4}$ e $56^{5}$, que tratou de desembarcar a previsão de anulação dos atos praticados em fraude da legislação falimentar.

Para tratar do sistema de ineficácias que comanda os efeitos da ação revocatória do art. $130^{6}$ da Lei n. 11.101/2005, é fundamental abordar o plano de existência, validade e eficácia do negócio jurídico. Essa abordagem - mais cuidadosa - permite que sejam evitados erros grosseiros no endereçamento dos efeitos provocados no julgamento procedente de eventual ação revocatória. Antônio Junqueira de Azevedo (1986) assim conceitua o negócio jurídico:

\footnotetext{
${ }^{3}$ Art. 828 - Todos os atos do falido alienativos de bens de raiz, móveis ou semoventes, e todos os mais atos e obrigações, ainda mesmo que sejam de operações comerciais, podem ser anulados, qualquer que seja a época em que fossem contraídos, enquanto não prescreverem, provando-se que neles interveio fraude em dano de credores. Art. 129 - São nulos todos os contratos comercias: 4 - que forem convencidos de fraude, dolo ou simulação (artigo $\mathrm{n}^{\circ} .828$ );

${ }^{4}$ Art. 55. Não produzirão efeito relativamente à massa, tenha ou não o contratante conhecimento do estado econômico do devedor, seja ou não intenção deste fraudar os credores: [...].

5 Art. 56. Poderão ser revogados, também, relativamente à massa, todos e quaisquer atos, enquanto não prescritos, praticados pelo devedor, na intenção de prejudicar credores, provando-se fraude de ambos os contraentes.

${ }^{6}$ Art. 130. São revogáveis os atos praticados com a intenção de prejudicar credores, provando-se o conluio fraudulento entre o devedor e o terceiro que com ele contratar e o efetivo prejuízo sofrido pela massa falida.
} 
In concreto, negócio jurídico é todo fato jurídico consistente em declaração de vontade, a que o ordenamento jurídico atribui os efeitos designados como queridos, respeitados os pressupostos de existência, validade e eficácia, impostos pela norma jurídica que sobre ele incide. (p. 20)

Em um raciocínio superficial sobre a existência, validade e eficácia do negócio jurídico poderia se afirmar que o efeito da ação revocatória é o de anular os atos praticados em fraude contra o devedor. Essa lógica não encontra guarida no atual direito falimentar, e o próprio vocábulo revocar indica a intenção de "fazer retornar" e não de tornar nulos os atos praticados em fraude contra credores. De outro turno, Antônio Junqueira de Azevedo (1986) propõe que o exame do negócio seja feito a partir de uma técnica de eliminação progressiva:

O exame do negócio, sob ângulo negativo, deve ser feito através do que batizamos com o nome de técnica de eliminação progressiva. Essa técnica consiste no seguinte: primeiramente, há de se examinar o negócio jurídico no plano da existência e, aí, ou ele existe, ou não existe. Se não existe, não é negócio jurídico, é aparência de negócio (dito "ato inexistente") e, então, essa aparência não passa, como negócio, para o plano seguinte, morre no plano da inexistência. No plano seguinte, o da validade, já não entram os negócios aparentes, e sim, somente os negócios existentes; aí, nesse plano, os negócios existentes serão, ou válidos, ou inválidos; se forem inválidos, não passam para o plano da eficácia, ficam no plano da validade; somente os negócios válidos continuam e entram no plano da eficácia. Nesse último plano, por fim, esses negócios, existentes e válidos serão ou eficazes ou ineficazes (ineficácia em sentindo restrito). (p. 74)

Em relação à ineficácia, duas podem ser as categorias: em sentido restrito e a superveniente, sendo esta última a ineficácia afeta à ação revocatória. Em ambas as categorias, se supõe válido o negócio, mas diferente da ineficácia superveniente, a ineficácia em sentido restrito existe desde a formação do ato. (AZEVEDO, 1986, p. 76)

Conforme já mencionado anteriormente, o efeito provocado pelo julgamento procedente da ação revocatória é constitutivo negativo para declarar a ineficácia relativa de determinado ato, especificamente, em relação à massa falida. De outro lado, segue hígido o negócio jurídico firmado inter partes, isto é, entre o falido e o terceiro que com ele contratou. Ao comentar o art. $57^{7}$ do Dec. Lei n. 7.661/1945, Trajano de Miranda Valverde (1962, p. 398) elucida a celeuma:

Vimos (n. 362) que a nossa legislação civil incluiu a fraude entre os defeitos ou vícios que atacam a substância do ato, tornando-os anuláveis, confundindo, por isso mesmo, a ação revocatória com a ação de anulação. Apesar disso, os efeitos da anulação do ato por fraude não abrangem senão as próprias partes e os terceiros de boa-fé tenham adquirido com fundamento nêle, o que é contrário à regra de que, anulado o ato, se considera como se nunca tivesse existido, desfazendo-se os direitos que os terceiros nêle baseados houvesses adquirido. Vê-se, pois, que a ação revocatória não é uma ação de anulação. [grifo nosso]

\footnotetext{
${ }^{7}$ Art. 57. A ineficácia do ato pode também ser oposta como defesa em ação ou execução, perdendo a massa o direito de propor a ação de que trata o artigo anterior.
} 
Essas distinções recebem menos atenção do que merecem, tornando comuns erros de comparação na teoria das nulidades. Antônio Junqueira de Azevedo (1986, p. 73-74) explica: "Portanto, temos: no plano da existência, o negócio existente e o negócio inexistente; no plano da validade o negócio válido e o negócio inválido (subdivido em nulo e anulável); e no plano da eficácia, o negócio eficaz e o negócio ineficaz em sentido restrito"

Nesse ponto, importa compreender a diferença existente entre os efeitos do negócio anulável com os efeitos do negócio ineficaz, considerando as pertinentes distinções observadas entre a ação pauliana, que uma vez procedente opera efeitos de anulabilidade e a ação revocatória, cuja procedência culmina na declaração de ineficácia de determinados atos, em relação à massa falida.

Se, de um lado, o negócio anulável pode ser livremente convalidado, não cabe intervenção do Ministério Público ou ajuizamento de ação pelo parquet, uma vez que o exercício do direito de ação é exclusivo das partes interessadas, não cabe decretação ex offício e opera efeitos inter partes (TARTUCE, 2015, p.275); de outro, a eventual procedência de declaração de ineficácia subjetiva tem como efeito a determinação de retorno dos bens à massa falida em espécie, acrescidos de perdas e danos e acessórios, aproveita a todos os credores da massa e não somente o autor da ação revocatória, garante o restabelecimento do status quo ante apenas em relação à massa falida e não ao falido - que tomou parte no negócio cometido em fraude (CLARO, 2005, p.80-81) - e pode ser ajuizada pelo Ministério Público, diferindo, também, neste ponto, do negócio anulável.

Uma vez endereçado o sistema de ineficácias que rege alguns dispositivos da lei falimentar vigente, é de curial importância indicar a diferença entre a ineficácia prevista no art. $129^{8}$ da Lei n. 11.101/2005, de caráter objetivo, com a ineficácia prevista no art. 130 da

\footnotetext{
${ }^{8}$ Art. 129. São ineficazes em relação à massa falida, tenha ou não o contratante conhecimento do estado de crise econômico-financeira do devedor, seja ou não intenção deste fraudar credores: I - o pagamento de dívidas não vencidas realizado pelo devedor dentro do termo legal, por qualquer meio extintivo do direito de crédito, ainda que pelo desconto do próprio título; II - o pagamento de dívidas vencidas e exigíveis realizado dentro do termo legal, por qualquer forma que não seja a prevista pelo contrato; III - a constituição de direito real de garantia, inclusive a retenção, dentro do termo legal, tratando-se de dívida contraída anteriormente; se os bens dados em hipoteca forem objeto de outras posteriores, a massa falida receberá a parte que devia caber ao credor da hipoteca revogada; IV - a prática de atos a título gratuito, desde 2 (dois) anos antes da decretação da falência; V - a renúncia à herança ou a legado, até 2 (dois) anos antes da decretação da falência; VI - a venda ou transferência de estabelecimento feita sem o consentimento expresso ou o pagamento de todos os credores, a esse tempo existentes, não tendo restado ao devedor bens suficientes para solver o seu passivo, salvo se, no prazo de 30 (trinta) dias, não houver oposição dos credores, após serem devidamente notificados, judicialmente ou pelo oficial do registro de títulos e documentos; VII - os registros de direitos reais e de transferência de propriedade entre vivos, por título oneroso ou gratuito, ou a averbação relativa a imóveis realizados após a decretação da
} 
mesma lei, de caráter subjetivo. Os precedentes judiciais demonstram que é frequente a confusão e o desconhecimento de juízes, credores e administradores judiciais sobre os efeitos pretendidos em cada dispositivo de declaração de ineficácia. É o que a doutrina também reporta:

\begin{abstract}
A experiência revela que em muitas petições forenses e mesmo em decisões judiciais vêm se atribuindo à circunstância de ter sido determinado negócio celebrado dentro do termo legal da falência uma relevância que a lei nunca estabeleceu - considera-se ou se quer considerar ineficaz este ou aquele ato apenas porque foi ele praticado dentro do chamado período suspeito. Data vênia, a erronia é de monta. A prática do ato nesse intervalo de tempo só é decisiva para impor-lhe a ineficácia nas hipóteses dos incisos I a III do art. 129 - em todas as demais previstas naquele dispositivo esse aspecto não tem a menor relevância. Aliás, pode suceder, e não será raro, que o ato ineficaz tenha nascido em data anterior ao termo. (TEPEDINO, 2016, p. 502) (grifos nossos)
\end{abstract}

O escólio de Ricardo Tepedino é pertinente porque apenas os primeiros três incisos do art. 129 se referem ao termo legal para fins de fixação da data paradigmática que passa a indicar os atos expostos à declaração de ineficácia objetiva. O termo legal encontra previsão no inciso II do art. $99^{9}$ da lei falimentar vigente. Sobre esse termo:

Salienta-se na doutrina moderna a importância da fixação do termo legal de forma
mais ampla. De fato, em legislações passadas, chegou-se a falar em 40 (quarenta)
dias e no Dec.-lei $7.661 / 1945$ deixou-se esta fixação a critério do Juízo, que poderia
fixá-lo em até 60 (sessenta) dias. Agora, na Lei 11.101/2005, o termo legal é de 90
(noventa) dias contados do pedido de falência, ou do pedido de recuperação
judicial, ou do primeiro protesto por falta de pagamento, excluindo-se, para
esta finalidade, os protestos que tenham sido cancelados. Como se vê do texto
da Lei, a fixação do termo legal tem importância decisiva para a declaração de
ineficácia dos atos nela mencionados. (MARTIN, 2007, p. 473)

Os incisos IV e V do art. 129, estabelecem como atacáveis os atos praticados a título gratuito, bem como a renúncia à herança ou a legado, se tais práticas foram adotadas no período de 2 (dois) anos antes da decretação da falência. O inciso VI, do mesmo artigo, informa que será ineficaz a venda ou transferência de estabelecimento feita sem o expresso consentimento ou o pagamento de todos os credores, quando não restarem ativos suficientes para fazer frente ao respectivo passivo. Já o inciso VII, informa que serão objetivamente ineficazes em relação à massa a transferência de propriedade entre vivos e os registros de direitos reais após a decretação da falência, excetuando-se os atos que tiverem sido prenotados anteriormente.

falência, salvo se tiver havido prenotação anterior. Parágrafo único. A ineficácia poderá ser declarada de ofício pelo juiz, alegada em defesa ou pleiteada mediante ação própria ou incidentalmente no curso do processo.

${ }^{9}$ Art. 99. A sentença que decretar a falência do devedor, dentre outras determinações: II - fixará o termo legal da falência, sem poder retrotraí-lo por mais de 90 (noventa) dias contados do pedido de falência, do pedido de recuperação judicial ou do $1^{\circ}$ (primeiro) protesto por falta de pagamento, excluindo-se, para esta finalidade, os protestos que tenham sido cancelados; 
Não é demais lembrar que o objetivo da ação revocatória é de provocar a ineficácia do negócio firmado em fraude contra credores, nos termos do art. 130 da Lei n. 11.101/2005, sendo irrelevante que o referido ato fraudulento tenha sido cometido dentro ou fora do termo legal. Assim, enquanto grande parte das hipóteses do artigo 129 estão atreladas a um elemento cronológico, no artigo 130 o legislador intencionalmente prescindiu desse elemento, o que não configura omissão, mas a manifestação de um silêncio eloquente. Neste caso, o silêncio revela o que constitui, ou não, o conteúdo da própria norma (MAXIMILIANO, 1979, p. 208).

Aliás, o fato de o ato fraudulento ter sido cometido dentro do termo legal poderá ser considerando - no melhor dos cenários - como indício que corrobora o fato constitutivo do direito do autor da ação revocatória, em razão da proximidade entre a data em que se firmou o negócio jurídico em prejuízo dos credores e dano suportado pela massa e a data de decretação da falência. Carlos Roberto Claro se posiciona no mesmo sentido:

Em consequência do até aqui exposto, o termo legal realmente é importante para a verificação dos atos praticados pelo devedor em período pretérito à falência, mas não é suficiente. Porém, o art. 130 da Lei 11.101/05 traça como requisitos indispensáveis à prova de fraude, prejuízo aos credores e a intenção de tal prática, sem condicionar a ação a qualquer lapso temporal. (CLARO, 2018, p.110)

Larga é, portanto, a distância que separa o art. 130 - que estabelece as premissas de ajuizamento da ação revocatória - de eventual discussão travada sobre a data fixada para fins de definição do termo legal da falência e a data do negócio jurídico que se pretenda declarar ineficaz.

A revocatória tampouco se encontra vinculada à indicação do período suspeito, que decorre de criação doutrinária e envolve conceito subjetivo e elástico, que depende do interlocutor que o desenvolve e da pretensão alvejada, isto é, de proteger eventual negócio praticado em fraude ou de buscar a ineficacização dos seus efeitos em relação à massa falida.

Yussef Said Cahali (2013, p. 539), confere definição mais completa sobre o período suspeito:

[...] embora empregadas indistintamente na doutrina as expressões "período suspeito e "termo legal", comporta esse uso certas precisões; na realidade, nem sempre elas são coincidentes: "período suspeito" é o tempo decorrido entre a manifestação do estado de insolvência e a sentença declaratória da falência; "termo legal", na explicitação da lei, é o lapso de tempo anterior contado do primeiro protesto por falta de pagamento, ou da distribuição da concordata (hoje recuperação judicial), se convolada esta em falência.

Diante de abalizada doutrina, há que se concordar que o termo legal e o período suspeito não impõem qualquer limitação temporal ao exercício do direito previsto no art. 130 
da Lei n. 11.101/2005, restando essas datas, única e exclusivamente, como recursos argumentativos dos quais pode o autor da ação revocatória lançar mão para demonstrar a proximidade de cometimento de ato fraudulento com a data de decretação da falência do devedor.

Adiante, serão indicados aspectos processuais que ratificam a posição até aqui defendida, no sentido de que não existe limitação temporal para que a declaração de ineficácia de ato praticado em fraude e prejuízos dos credores da massa falida seja questionado judicialmente. Há, no entanto, prazo legal para ajuizamento da medida judicial, é o que se passa a expor.

\section{ASPECTOS PROCESSUAIS DA AÇÃO REVOCATÓRIA}

Antes que se faça qualquer digressão sobre o prazo de ajuizamento da ação revocatória, há que se registrar que o elemento central em debate é a inexistência de limitação temporal para atingimento de atos praticados em fraude contra credores da massa falida. Certo é que, como qualquer medida judicial, a ação revocatória tem aspectos de natureza material, que nesse caso é o próprio ato cuja eficácia se busca alterar em favor da massa; e outro aspecto de natureza processual. Enquanto não há imposição de limite temporal para que, por meio da ação revocatória, se atinja atos fraudulentos praticados no passado (recente ou distante), há, evidentemente, prazo processual delimitado para ajuizamento da medida, sob pena de esse direito ser fulminado pela decadência.

Sob o aspecto processual, é relevante lembrar que a ação revocatória trata de procedimento ordinário, de caráter coletivo, que demanda produção de prova de dano causado à massa falida, bem como demonstração do consilium fraudis entre os contratantes que se aproveitaram do respectivo ato.

Como já dito, o direito ao exercício da ação revocatória é fulminado pela decadência quando não exercido no prazo de 3 (três) anos, a contar da decretação da quebra, nos termos do art. $132^{10}$ da Lei Falimentar vigente. Tal constatação não revela surpresa, porque o art. 57 do decreto revogado já ostentava a mesma natureza decadencial albergada pelo vigente art. 132:

A parte final do dispositivo ora comentado preceitua que a ação revocatória deverá ser proposta no prazo de três anos contado da decretação da falência. Cuida-se,

\footnotetext{
${ }^{10}$ Art. 132. A ação revocatória, de que trata o art. 130 desta Lei, deverá ser proposta pelo administrador judicial, por qualquer credor ou pelo Ministério Público no prazo de 3 (três) anos contado da decretação da falência.
} 
induvidosamente, de prazo decadencial, como, aliás, já reconhecia a doutrina e a jurisprudência que examinaram o art. 57, $\S 1^{\circ}$, da LF revogada, pelo que o seu decurso faz desaparecer a oportunidade de se alegar a existência de ato fraudulento lesivo aos credores. (TEPEDINO, 2016, p. 505)

O mesmo dispositivo que regula a limitação temporal para ajuizamento da ação revocatória é o que legitima o credor e o Ministério Público a intentar a medida judicial, além do administrador judicial - que estará, neste ato, representando os interesses da massa falida, logo, a legitimação cabe à massa falida e não à pessoa do administrador judicial, que somente a estará representando.

É pertinente lembrar que a lei falimentar revogada dispunha de forma pouco diferente acerca da legitimação e do prazo de ajuizamento da ação revocatória, uma vez que legitimava esses atores processuais (Ministério Público e Credores) de forma subsidiária e somente depois que o próprio síndico (atual administrador judicial) não intentava a medida. A esse respeito:

Diz a norma que a ação revocatória, que ela indica como remédio processual adequado para que se alcance a revogação de atos lesivos, na forma do art. 130 (embora o faça de maneira oblíqua, referindo-se à ação de que trata o aludido dispositivo), poderá ser proposta pelo administrador, pelo Ministério Público ou por qualquer credor. Portanto, a legitimação ativa dos credores é concorrente, e não subsidiária, como na lei anterior, quando estes só poderiam ajuizar a medida se o então síndico não o fizesse no prazo marcado pelo caput do art. 55 da Lei de 1945. (TEPEDINO, 2016, p. 504)

No que trata do prazo para ajuizamento da ação revocatória, há que se rememorar que na legislação revogada o cômputo desse prazo não se dava de forma tão objetiva como a que se estabeleceu na legislação vigente, por meio do art. 132 da LRE:

\footnotetext{
No Dec. - Lei $7.661 / 1945$, art. $56, \S 1^{\circ}$, o prazo para a propositura da ação revocatória era de um ano, contado da publicação do aviso do síndico sobre o início da realização do ativo e pagamento do passivo. Havia, no entanto, inconvenientes e discussões em torno do prazo decadencial, que se iniciava da publicação do aviso de comunicação aos interessados da realização do ativo (art. 56, § $1^{\circ}$ ). Entendiam doutrina e jurisprudência que, no caso de inércia do síndico na publicação do aviso a que aludia o art. 114, o termo inicial do prazo seria a partir de quando deveria ter sido expedido o aviso ou encerrada a falência. (AZZONI, 2018, p. 334)
}

Atualmente, essa celeuma encontra-se superada, porque, nos termos do art. 132 da LRE, a ação revocatória do art. 130 da mesma lei deverá ser proposta, por qualquer dos seus legitimados, no prazo de 3 (três) anos, contados da decretação da falência.

Clara Moreira Azzoni alerta que, apesar da clareza do comando do art. 132 quanto ao prazo de propositura da ação revocatória, há que se atentar à eventual dificuldade de verificar a data da "decretação da falência". Segundo sustenta a autora, o prazo decadencial deve ser computado a partir da data de disponibilização da sentença de quebra e não da sua publicação 
ou intimação dos credores, nos termos do art. $99^{11}$ da LRE. (2018, p. 335). Na mesma linha, Sérgio Campinho registra que:

[...] pode ser a ação proposta a partir da abertura do processo de falência, quando então, surge a massa falida. O dies a quo, isto é, o termo inicial para o ajuizamento é a data da decretação da falência. Decai o direito à ação revocatória, quando fundada nos atos revogáveis do art. 130, em três anos, computados da decretação da falência (art. 132). O prazo terá início, efetivamente, não da data de publicação da sentença no órgão oficial, mas sim do dia em que foi assinada pelo juiz, pois daí decorrem, desde logo, os efeitos materiais daquele estado, conforme sustentamos no item 161 supra. (2018, p. 351-352)

O direito do legitimado a intentar ação revocatória estaria também fulminado se, mesmo antes do decurso do prazo prescricional de 3 (três) anos o procedimento falimentar fosse encerrado, sem que a medida estivesse distribuída. Isso porque, a ação revocatória só tem lugar na falência e, depende, portanto, da tramitação desse procedimento para que possa alcançar os efeitos nela pretendidos. Trata-se de uma condição de procedibilidade, ou seja, uma condição especial somente aplicável à revocatória.

Em outra hipótese, a revocatória perderia o objeto e teria seu julgamento prejudicado se, em determinada circunstância, o procedimento falimentar fosse encerrado antes do seu julgamento. A solução não causa estranheza porque no encerramento da falência, importa que ou os credores da massa foram satisfeitos, ou a decisão de quebra foi reformada por qualquer

\footnotetext{
${ }^{11}$ Art. 99. A sentença que decretar a falência do devedor, dentre outras determinações: I - conterá a síntese do pedido, a identificação do falido e os nomes dos que forem a esse tempo seus administradores; II - fixará o termo legal da falência, sem poder retrotraí-lo por mais de 90 (noventa) dias contados do pedido de falência, do pedido de recuperação judicial ou do $1^{\circ}$ (primeiro) protesto por falta de pagamento, excluindo-se, para esta finalidade, os protestos que tenham sido cancelados; III - ordenará ao falido que apresente, no prazo máximo de 5 (cinco) dias, relação nominal dos credores, indicando endereço, importância, natureza e classificação dos respectivos créditos, se esta já não se encontrar nos autos, sob pena de desobediência; IV - explicitará o prazo para as habilitações de crédito, observado o disposto no $\S 1^{\circ}$ do art. $7^{\circ}$ desta Lei; $\mathbf{V}$ - ordenará a suspensão de todas as ações ou execuções contra o falido, ressalvadas as hipóteses previstas nos $\S \S 1^{0} \mathrm{e}$ e $2^{\underline{0}}$ do art. $6^{\circ}$ desta Lei; VI - proibirá a prática de qualquer ato de disposição ou oneração de bens do falido, submetendo-os preliminarmente à autorização judicial e do Comitê, se houver, ressalvados os bens cuja venda faça parte das atividades normais do devedor se autorizada a continuação provisória nos termos do inciso XI do caput deste artigo; VII - determinará as diligências necessárias para salvaguardar os interesses das partes envolvidas, podendo ordenar a prisão preventiva do falido ou de seus administradores quando requerida com fundamento em provas da prática de crime definido nesta Lei; VIII - ordenará ao Registro Público de Empresas que proceda à anotação da falência no registro do devedor, para que conste a expressão "Falido", a data da decretação da falência e a inabilitação de que trata o art. 102 desta Lei; IX - nomeará o administrador judicial, que desempenhará suas funções na forma do inciso III do caput do art. 22 desta Lei sem prejuízo do disposto na alínea $a$ do inciso II do caput do art. 35 desta Lei; $\mathbf{X}$ - determinará a expedição de ofícios aos órgãos e repartições públicas e outras entidades para que informem a existência de bens e direitos do falido; XI pronunciar-se-á a respeito da continuação provisória das atividades do falido com o administrador judicial ou da lacração dos estabelecimentos, observado o disposto no art. 109 desta Lei; XII - determinará, quando entender conveniente, a convocação da assembléia-geral de credores para a constituição de Comitê de Credores, podendo ainda autorizar a manutenção do Comitê eventualmente em funcionamento na recuperação judicial quando da decretação da falência; XIII - ordenará a intimação do Ministério Público e a comunicação por carta às Fazendas Públicas Federal e de todos os Estados e Municípios em que o devedor tiver estabelecimento, para que tomem conhecimento da falência.
} 
motivo de fundo processual, fazendo desaparecer os legitimados da revocatória e, consequentemente interesse processual que justifique sua manutenção. A ação revocatória é, portanto, acessória do procedimento falimentar e acompanharia o destino do processo principal.

Entendendo que a discussão de fundo processual é suficiente para o fim aqui pretendido, há que se enfrentar uma das hipóteses suscitadas no preâmbulo da reflexão proposta, no que refere à suposta omissão por parte do legislador que não fixou limitação temporal para o ato que se pretende ver revogado em relação à massa.

\section{ASPECTOS HISTÓRICOS SOBRE A AÇÃO REVOCATÓRIA}

Não é incomum verificar na doutrina comparações bem-vindas entre a ação revocatória falimentar e a ação pauliana, prevista no art. 158 do Código Civil. Inegável que essas medidas judiciais se assemelhem, mas há também que se reconhecer a larga distância que as separam.

Para enfrentar a primeira hipótese sugerida no presente trabalho, é preciso supor que a inexistência de limitação temporal para os atos que podem ser atingidos pela declaração de ineficácia da revocatória falimentar foi provocada por omissão do legislador. Assumindo que a hipótese é de omissão, tal lacuna poderia ser remediada por meio de técnica de integração do direito, nos termos do art. $4^{\mathrm{a}}{ }^{12}$ da Lei de Introdução às Normas do Direito Brasileiro. A analogia se apresentaria, portanto, para sanar essa falha do "desatento" legislador.

Admita-se, ad argumentandum tantum, que o julgador poderia invocar o inciso II do art. 178 do Código Civil, cuja serventia é de estabelecer - justamente o que a legislação falimentar não faz - um limite temporal para que os negócios jurídicos firmados em fraude sejam anulados, nos termos do art. 158 do Código Civil. O dispositivo é de fácil compreensão e dispensa maiores digressões. Em suma: o inciso II do art. 178 determina que fica convalidado o negócio jurídico praticado em fraude contra credores se o legitimado a tanto não exercer seu direito de ação no prazo de 4 (quatro) anos, a contar data em que se realizou o negócio jurídico.

Acaso aplicado de forma analógica o inciso II do art. 178 do Código Civil para suprir a propalada lacuna deixada pelo legislador que - supostamente - quedou silente em relação à

\footnotetext{
${ }^{12}$ Art. 4ํㅜㄹ Quando a lei for omissa, o juiz decidirá o caso de acordo com a analogia, os costumes e os princípios gerais de direito.
} 
limitação temporal do ato que pode ser atingido via revocatória falimentar, estar-se-ia impondo à norma de direito falimentar o sistema de anulabilidades da legislação cível.

Do seu lado, o art. 130 da LRE não encontra nos artigos que o sucedem nenhuma disposição legal que imponha limites temporais para o ato que se pretende ver revogado, à exceção do art. 132, que trata do prazo processual de ajuizamento da ação revocatória, mas não de limitação temporal em relação ao ato cuja eficácia será relativizada em relação à massa.

A utilização da interpretação analógica para solução de um problema processual concreto só tem cabimento quando a lei é omissa e não quando referida omissão está carregada de intenção específica e direcionada ao tratamento de determinada matéria, como é o caso do silêncio do legislador no art. 130 da Lei n. 11.101/2005, em relação ao aspecto temporal que convalide atos praticados em fraude pelo simples decurso do tempo. Então não é possível confundir o silêncio do legislador com a sua omissão, pois o primeiro é intencional, enquanto a segunda não é. E a intenção é valorada pelo direito.

E essa conclusão é possível, por exemplo, a partir da análise do sistema de existência, validade e eficácia que rege cada legislação. Isso porque, enquanto o art. 158 do Código Civil é regido pelo sistema das anulabilidades, o art. 130 da LRE é regido pelo sistema da ineficácia, emprestando-se ao primeiro o efeito de anulação do ato realizada em fraude e ao segundo ineficacização relativa em relação à massa, mantendo-se o negócio hígido entre as partes contratadas. Então, enquanto no primeiro caso o ato deixa de existir, no segundo o ato mantém-se vivo, mas é inoponível à massa falida.

Não se pode ignorar que a razão de existir do inciso II do art. 178 do Código Civil é justamente impor convalidação ao ato que se pretenda ver anulado, depois de decorridos 4 (quatro) anos de sua realização, ao passo que a legislação falimentar, em seu art. 130, eloquentemente, não o faz.

Por fim, cumpre mencionar que o prazo decadencial da ação revocatória falimentar
não se confunde com o prazo decadencial de quatro anos da ação pauliana (art. 178,
inc. II do Código Civil). Esses remédios processuais têm aplicação distinta e, depois
de iniciado o processo falimentar, a fraude contra credores deve ser combatida por
meio das ferramentas previstas na legislação falimentar, aplicando-se, pois, o prazo
decadencial do art. 132 da LRE. (AZZONI, 2018, p. 337)

A elucidação propiciada pelo raciocínio desenvolvido por Clara Moreira Azzoni no trecho acima transcrito é suficiente para refutar a hipótese que admite que o legislador foi omisso em relação à fixação de data limite em relação aos atos que podem ter eficácia relativizada em reação à massa. 
Mantendo a coerência de sua obra, quando compara os efeitos da anulabilidade e da ineficácia, Yussef Said Cahali (2013, p. 524) discorda frontalmente do raciocínio de que o art. 130 não estabelece limite temporal máximo para o ato que pode ser atacado via ação revocatória:

\begin{abstract}
Fora do termo legal da falência (ou de algum prazo especial previsto), caberia apenas a pauliana de direito comum, segundo as disposições dos arts. 158 e 159 do CC, embora a recuperação do bem deva reverter a benefício da massa (art. 165 do CC). Não nos parece lógico nem compatível com a segurança dos negócios jurídicos que os atos praticados pelo devedor mais de dois anos antes da decretação da falência (fora, portanto, do limite do art. 129, IV e V), já atingidos eventualmente pela decadência quadrienal do art. 178, II, do CC, possam posteriormente ser declarados ineficazes em razão de superveniente falência do doador ou herdeiro renunciante. (2013, p. 594)
\end{abstract}

Para o autor, que defende posição contrária àquela sustentada neste artigo, também os "atos" previstos no art. 130 da LRE teriam de estar temporalmente localizados dentro do termo legal da falência, em que pese o referido dispositivo não fazer qualquer menção ou alusão ao referido período.

Não é possível aquiescer com essa conclusão, pois tal espécie de raciocínio malfere o artigo da revocatória e convalida as mais criativas e bem organizadas fraudes que passariam a estar acobertadas pelo mero decurso do tempo. A depender da data fixada como termo legal da falência, seria impossível para o credor prejudicado e a própria massa molestada pela fraude, buscar qualquer ressarcimento contra os atos do referido negócio praticado em conluio entre o falido e a parte que com ele contratou.

Enfrentando a segunda hipótese proposta nessa reflexão, é momento de analisar se é eloquente o silêncio do legislador em relação à não limitação temporal dos atos que podem ser atacadas via revocatória falimentar

\title{
4. A DECADÊNCIA DO DIREITO À REVOGAÇÃO DO ATO VIS-A-VIS A ÉPOCA DE SUA PRÁTICA ANTES DA FALÊNCIA
}

O ordenamento jurídico deve funcionar de forma concatenada e coerente. Nesse passo, é razoável admitir que o legislador, ciente de que o diploma civil já estabeleceu limite temporal para que a parte legitimada proponha a ação pauliana objetivando a anulação de negócios jurídicos firmados em fraude, tenha, propositadamente, estatuído não impor o mesmo limite para que se persiga ativos transferidos ou cedidos em fraude da sociedade empresária cuja quebra tenha sido decretada. 
Isso porque, depois de falida, a sociedade perde a sua capacidade de administração, enfrentando o fenômeno do desapossamento e dando lugar à figura jurídica da massa falida (LEONEL, 1951, p.29). Nesse cenário, é crível e natural que o legislador tenha tido o cuidado de não convalidar - pelo mero decurso do tempo - atos que possam ter contribuído expressivamente para agravar ou postar o devedor em estado falimentar. E este foi o objetivo do legislador na hipótese analisada, não se tratando, assim, de omissão, mas de silêncio intencional.

Assim, é absolutamente possível admitir que o legislador tenha emprestado caráter excepcional às regras que regem as relações jurídicas quando o cenário é a falência. Para tanto, o legislador oportunizou à massa e aos credores rever negócios jurídicos possivelmente engendrados em prejuízo dos seus créditos, direitos e interesses, mesmo que tais atos já não mais pudessem ser atacados por meio da ação pauliana, em razão do decurso do prazo decadencial que fulmina esse direito na legislação civil.

Clara Moreira Azzoni (2018, p. 309) comenta a respeito do tema:

Entendemos que o silêncio do legislador foi proposital, justamente para que possa ser avaliado, em cada caso concreto, se estão presentes os elementos para a configuração da fraude e revogação do ato, tornando-o ineficaz em relação à massa falida. Trata-se de uma forma de ampliar a aplicação do instituto, fortalecendo a análise dos requisitos próprios para a procedência dos pedidos.

A posição adotada pela autora é concertada às normas do direito falimentar, porque seria temerário supor que a decadência prevista no inciso II do art. 178 do Código Civil fulminaria - a reboque - o direito do credor da massa falida de reaver ativo extraído do patrimônio da massa, em razão de conluio praticado pelo devedor e deste com um terceiro.

Demais disso, enquanto o art. 178 encontra-se inserido no Capítulo V do Código Civil, que trata da invalidade do negócio jurídico e trata vícios desse dispositivo no regime das anulabilidades, fato é que não se pode simplesmente transpor o prazo de 4 (quatro) anos para convalidação do ato que se queira ver declarado ineficaz em sede de ação revocatória, porque o regime falimentar que toca essa ação é o da ineficácia e não da anulabilidade.

Some-se, ainda, o fato de que no sistema especial o artigo 129, a LRE dispensa o elemento fraude, enquanto o artigo 130 trata do oposto, ou seja, dos casos em que há conluio fraudulento. Portanto, correta a posição do legislador em não fixar nenhum elemento temporal capaz de convalidar atos praticados fraudulentamente.

A jurisprudência confirma o raciocínio aqui exposto, ao demonstrar que o elemento temporal, relacionado ao momento em que o ato foi praticado, não constitui de per si 
motivação de improcedência ou de extinção de ação revocatória, sendo a análise desse aspecto, inclusive, dispensável no julgamento da revocatória falimentar. A título de ilustração são brevemente analisados alguns casos levados a julgamento perante o Superior Tribunal de Justiça e o Tribunal de Justiça do Rio Grande do Sul:

Caso 1: a decisão da Quarta Turma do STJ no Recurso Especial n. 302.558/RJ, julgado em 01/03/2007, sob a relatoria do Min. Aldir Passarinho Junior, ratifica a necessidade da demonstração do consilium fraudis entre a sociedade empresária alienante posteriormente falida - e o adquirente do imóvel, para que restasse comprovada a invalidade da venda, pouco importando que referido negócio jurídico tenha sido realizado dentro do chamado "período suspeito".

COMERCIAL E PROCESSUAL CIVIL. AÇÃO REVOCATÓRIA. FALÊNCIA. VENDA DE IMÓVEL ANTES DA SENTENÇA DE QUEBRA, DENTRO DO PERÍODO SUSPEITO. FRAUDE NÃO DEMONSTRADA. EFICÁCIA DO NEGÓCIO JURÍDICO. DECRETO-LEI N. 7.661/1945. I. A invalidade da venda de imóvel pela empresa antes da decretação da sua falência, dentro do período suspeito, depende da prova concreta da fraude, consoante a orientação firmada no STJ. II. Recurso especial conhecido e provido. Ação revocatória improcedente. [grifo nosso]

Trata-se de recurso especial, interposto em face de acórdão exarado pelo Tribunal de Justiça do Estado do Rio de Janeiro que declarou ineficaz negócio jurídico firmado entre o recorrente, que figurou nessa relação como adquirente do imóvel pertencente à sociedade empresária, cuja falência veio a ser decretada após a aquisição do referido bem.

O recorrente alega que o negócio teria sido realizado no chamado "período suspeito" e que o Tribunal Justiça Estadual entendeu pela declaração de ineficácia do ato, sem se imiscuir na verificação do elemento fraude, por entender que a hipótese se amoldava no inciso VIII do art. $52^{13}$ da lei falimentar revogada.

Conforme se extrai do relatório do acórdão do recurso especial, a Quarta Turma do STJ considerou a divergência suficientemente demonstrada, no sentido de que a invalidade da venda realizada no "período suspeito" depende da comprovação do conluio fraudulento entre o terceiro adquirente e a sociedade empresária, mais tarde falida, em consonância com os julgados do Superior Tribunal.

\footnotetext{
${ }^{13}$ Art.52. Não produzem efeitos relativamente à massa, tenha ou não o contratante conhecimento do estado econômico do devedor, seja ou não intenção dêste fraudar credores: VIII - a venda, ou transferência de estabelecimento comercial ou industrial, feita sem o consentimento expresso ou o pagamento de todos os credores, a êsse tempo existentes, não tendo restado ao falido bens suficientes para solver o seu passivo, salvo se, dentro de trinta dias, nenhuma oposição fizeram os credores à venda ou transferência que lhes foi notificada; essa notificação será feita judicialmente ou pelo oficial do registro de títulos e documentos.
} 
Nesse caso, ficou evidente a irrelevância de se constatar que o ato que se pretende ver declarado ineficaz tenha ocorrido dentro ou fora do período considerado "suspeito" porque o tempo em que foi firmado o negócio jurídico atacado não constitui elemento objetivo nem subjetivo do art. 130 para fins de formação do fato constitutivo do direito do autor que pretenda ver declarada ineficácia relativa de determinada operação.

Caso 2: a decisão proferida pela Terceira Turma do STJ no Recurso Especial n. 823.336/SP, julgado em 13/03/2017, sob a relatoria do Min. Ari Pargendler ratifica que a declaração de ineficácia de determinado negócio jurídico independe da data fixada a título do termo legal da falência, podendo, inclusive, ser declarada em alienações que ocorreram antes desse intervalo temporal, desde que preenchidos os demais requisitos necessários ao julgamento da revocatória falimentar, quais sejam: a demonstração do consilium fraudis e do dano causado à massa falida.

COMERCIAL. FALÊNCIA. TERMO LEGAL. ALIENAÇÃO DE BENS. A alienação de imóvel não é ineficaz pelo só fato de ter sido realizada no termo legal da falência; a ineficácia independe desse termo, podendo ser declarada mesmo se a alienação ocorreu antes dele - subordinada, todavia, à comprovação, nos autos de ação própria, de que os bens da falida foram distraidos em proveito dos sócios ou de terceiros. Recurso especial não conhecido. [grifo nosso]

O caso sob análise, trata de hipótese em que o Banco credor, arrendador de determinado bem imóvel, opôs embargos de terceiro nos autos de um procedimento falimentar para reclamar a propriedade de imóvel que ainda estaria na posse e propriedade da massa falida, mesmo depois de inadimplido o contrato de arrendamento mercantil com opção de compra. Referidos embargos foram julgados improcedentes pelo juízo de primeira instância, ao argumento de que o contrato de arrendamento mercantil celebrado entre o Banco credor e o devedor - agora falido - não seria eficaz em relação à massa, nos termos do inciso VIII, do art. 52 do decreto lei revogado, porque referida avença teria sido registrada dentro do termo legal da falência.

A Sexta Câmara de Direito Privado do Tribunal de Justiça do Estado de São Paulo reformou a decisão de primeiro grau e deu provimento ao recurso de apelação interposto pelo Banco credor para liberar o imóvel objeto dos embargos em seu favor, emprestando à questão o tratamento usualmente conferido aos embargos de terceiro, sem se imiscuir na eventual necessidade de ajuizamento de ação específica, em razão da peculiaridade do caso e do estado falimentar do devedor que alienou o bem, objeto de discussão nos embargos.

Pelo que se verifica do acórdão, a turma julgadora ponderou que as dificuldades financeiras enfrentadas pela falida, ré nos embargos de terceiro, se iniciaram no ano de 1993, 
enquanto a venda do imóvel foi celebrada no ano de 1990, antes, portanto, do período de dificuldade financeira que culminou na decretação de sua falência.

Nesse sentido, concluiu-se que, quando foi celebrada referida alienação, os credores foram satisfeitos e a alienante ostentava situação de solvabilidade, não sendo pertinente, portanto, a incidência do inciso VIII do art. 52 do decreto lei revogado. Nesse passo, somente se poderia cogitar da ineficácia do negócio, com amparo no art. 53 do decreto lei revogado, isto é, se presente estivesse o elemento fundamental de constituição do direito do autor: o consilium fraudis.

Esse entendimento foi modificado no julgamento dos embargos de declaração julgados pelo Des. Ernani de Paiva, momento em que ponderou a idoneidade da transação, em razão de o falido não ter firmado autêntico negócio de venda. Isso porque, o falido teria promovido a alienação do imóvel para em seguida recuperá-lo mediante a subscrição de contrato de arrendamento mercantil com opção de compra. Não fosse isso o suficiente, as contraprestações devidas em razão do arrendamento não foram regularmente quitadas, motivo pelo qual o bem foi reintegrado à posse pleiteada pelo Banco credor.

Não obstante a diversidade de indícios de cometimento de fraude, a Terceira Turma do Superior Tribunal de Justiça concluiu que a suspeita de que o falido promoveu alienação de bens em proveito dos sócios ou de terceiros deve ser objeto de ação própria. Além disso, concluíram que a mera alienação do imóvel no termo legal da falência não torna o ato ineficaz, uma vez que a ineficácia independe da data fixada nesse termo, podendo ser declarada mesmo quando o negócio ocorre antes dele.

A ementa do julgado confirma esse entendimento ao colocar em destaque a conclusão de que a alienação de determinado bem não é ineficaz só pelo fato de ter sido realizada no termo legal da falência, ratificando que a declaração de ineficácia independe desse termo.

Caso 3: a última decisão objeto de análise, foi proferida pela Quinta Câmara Cível do Tribunal de Justiça do Rio Grande do Sul, no Recurso de Apelação n. 70028062156, julgado em 12/08/2009, sob a relatoria do Des. Romeu Marques Ribeiro Filho, e se presta a demonstrar que o tempo de 7 (sete) anos, transcorrido entre a data de realização do negócio jurídico, cuja ineficácia se pretendia ver declarada em relação à massa, e a data de decretação da falência não foi fator sequer mencionado na decisão que julgou improcedente o pedido de revocação. Para a turma julgadora, o fator preponderante para desprovimento do recurso 
manejado pela massa foi a ausência de comprovação de má-fé, isto é, do consilium fraudis, entre as partes contratantes.

APELAÇÃO CÍVEL. FALÊNCIA E CONCORDATA. EMBARGOS DE TERCEIRO. Contrato particular de promessa de compra e venda firmado em 1992. Quitação. Quebra decretada em 1999. Arrecadação do bem pela falida. Alegação da massa de ineficácia da contratação. Ação Revocatória. Art. 53 da lei de falências. Consilium fraudis não demonstrado. A ação revocatória exige a demonstração do consilium fraudis entre o falido e o terceiro com quem contratou. Não há indícios nos autos de que tenham os embargantes, ao adquirir o imóvel da embargada, agido com má-fé, ou seja, com a intenção de fraudar. Sentença mantida. APELO DESPROVIDO. [grifos nossos]

$\mathrm{Na}$ origem, o processo versava sobre embargos de terceiro opostos nos autos do procedimento falimentar, no qual se promoveu arrecadação de imóvel adquirido pelos embargantes. O negócio jurídico atacado pela massa, se tratava da alienação do imóvel que foi firmada entre os embargantes e a devedora no ano de 1992, ao passo que o pedido de falência da devedora, depois falida, ocorreu no ano de 1999, cerca de 7 (sete) anos após o ato que a massa falida pretendia ver revogado.

A sentença que determinou a restituição do imóvel para os embargantes foi mantida pelo Tribunal de Justiça do Rio Grande do Sul. O acórdão que desproveu a apelação manejada pela massa falida foi fundamentado na ausência de indícios suficientes para comprovar que os embargantes tivessem agido de má-fé ao adquirir o imóvel da devedora, depois falida. A massa falida sustentou que os embargantes tinham ciência da irregularidade do negócio, pois, na ocasião de alienação do bem imóvel, a sociedade devedora não pôde fornecer a Certidão Negativa de Débitos (CND), fato que teria inviabilizado o registro da venda do imóvel e que apareceria como indício do estado de insolvência.

Tanto o juízo de origem, da Comarca de Novo Hamburgo, quanto a Quinta Câmara Cível do Tribunal de Justiça do Rio Grande do Sul entenderam que a mera existência de débitos em nome da falida não caracterizou fraude, elemento central para procedência de um pedido revocatório. Curial observar que o tempo de 7 (sete) anos que separa o ato, cuja eficácia se pretendia ver revogada, da decretação da falência, sequer foi utilizado como parte da fundamentação de improcedência do pedido de ineficácia, reforçando que tal espécie de argumento descabe para julgamento de ação revocatória.

O julgado é de relevante utilidade para o estudo que ora se propõe, considerando que 7 (sete) anos separaram a alienação atacada da quebra da devedora, proprietária do bem. Isso demonstra que não é relevante a data em que toma lugar o negócio realizado em prejuízo dos credores, uma vez que a data de realização do negócio não é parâmetro e nem requisito legal 
para admissão ou julgamento da ação revocatória. O decurso do tempo deve concorrer, $a d$ argumentandum, como elemento subjetivo e argumentativo a ser utilizado pelas partes da forma que lhes convier, na defesa dos seus interesses e não como elemento objetivo de procedência ou improcedência da ação revocatória.

\section{CONCLUSÃO}

Embora seja dissidente a doutrina sobre o tema, a conclusão do estudo ora proposto é de que o silêncio do legislador em relação à limitação temporal - do momento em que foi praticado o ato que se pretende ver revogado - é eloquente e proposital.

O entendimento de que teria sido deixada lacuna por parte do legislador quanto à propalada limitação temporal (quanto ao momento da prática do ato), não resiste à análise doutrinária e jurisprudencial sobre o tema, tendo sido demonstrado que os elementos verificados na constituição do direito da revocatória são o consilium fraudis e do dano à massa, nunca a data em que se realizou o negócio jurídico.

Outro importante aspecto refutado, em relação à suposta omissão legislativa, fica evidenciado pela impossibilidade de se invocar a utilização analógica do inciso II, do art. 178 do Código Civil para suprimir a suposta lacuna legal, porque referido dispositivo do diploma civil é orientado pelo regime da anulabilidades, ao passo que o art. 130 da Lei n. 11.101/2005 é orientado pelo regime da ineficácia, porque torna o negócio ineficaz apenas em relação à massa, remanescendo os efeitos do referido ato entre as partes contratadas.

Por fim, há que se admitir que o silêncio proposital e eloquente do legislador está carregado da clara intenção de não convalidar atos praticados em fraude de credores e prejuízo para a massa, não importando o momento em que foram praticados os atos atacáveis via revocatória falimentar. E isso se dá, porque a revocatória falimentar é um instrumento de defesa coletivo que só tem lugar na falência, última ocasião e oportunidade para que credores e massa falida, uma vez lesados por atos fraudulentos, possam se socorrer da tutela jurisdicional, sem que tais fraudes estejam acobertadas e convalidadas pelo mero decurso do tempo.

\section{REFERÊNCIAS}

AZEVEDO, Antônio Junqueira. Negócio jurídico: existência, validade e eficácia. 2- ed. São Paulo: Saraiva, 1986. 
BRASIL. Superior Tribunal de Justiça. Recurso Especial n. 302.558/RJ. Quarta Turma. Rel.: Min. Aldir Passarinho Junior. Brasília, 1 de março de 2007. Disponível em http://www.stj.jus.br. Acesso em 26 mar. 2019.

BRASIL. Recurso Especial n. 823.336/SP. Terceira Turma. Rel.: Ari Pargendler. Brasília, 13 de março de 2007. Disponível em http://www.stj.jus.br. Acesso em 26 mar. 2019

CAHALI, Yussef Said. Fraude contra credores: fraude contra credores, fraude à execução, ação revocatoria falencial, fraude à execução fiscal e fraude à execução penal. 5. ed.. rev. atual. São Paulo: Editora Revista dos Tribunais, 2013.

CAMPINHO, Sérgio. Curso de direito comercial: falência e recuperação de empresa. 9. ed.. São Paulo: Saraiva Educação, 2018.

CLARO, Carlos Roberto. Revocatória Falimentar: de acordo com a nova lei de falências. 3. ed.. rev. atual. e ampl. com base na Lei 11.101 de 09.02.2005. Curitiba: Juruá Editora, 2005.

GONÇALVES, Carlos Roberto. Direito civil brasileiro. v. I: parte geral. 5. ed.. rev. atual. São Paulo: Saraiva, 2007.

JOTA. Eduardo Coube de Carvalho. Descrédito. A ineficiência do atual processo de recuperação judicial de empresas no Brasil. Disponível em https://www.jota.info/opiniao-eanalise/artigos/a-ineficiencia-do-atual-processo-de-recuperacao-judicial-de-empresas-nobrasil-21012019\#sdfootnote1anc. Acesso em 04 abr. 2019.

LEONEL, Jayme. Da Ação Revocatória no Direito da Falência. 2. ed.. São Paulo: Saraiva, 1951.

MARTIN, Antonio. Seção IX: Da Ineficácia e da revogação de atos praticados antes da falência. In.: SOUZA JUNIOR, Francisco Satiro; PITOMBO, Antônio Sérgio A. de Moraes (Coord.). Comentários à Lei de recuperação de empresas e falência: Lei 11.101/2005. São Paulo: Editora Revista dos Tribunais, 2007.

MAXIMILIANO, Carlos. Hermenêutica e aplicação do direito. Rio de Janeiro: Forense, 1979.

MENDONÇA, José Xavier Carvalho de. Tratado de direito comercial brasileiro. v. VII. 7. ed.. Rio de Janeiro: Freitas Bastos, 1964.

REQUIÃO, Rubens. Curso de direito falimentar. v. I. 17.ed. São Paulo: Saraiva, 1998.

RIO GRANDE DO SUL (Estado). Recurso de Apelação n. 70028062156. Apelante: Massa Falida de S. N. Muller e Cia. Ltda. Quinta Câmara Cível. Rel.: Desembargador Romeu Marques Ribeiro Filho. Porto Alegre, 12 de agosto de 2009. Disponível em http://www.tjrs.jus.br. Acesso em 4 abr. 2019.

TARTUCE, Flavio. Manual de direito civil: v. único.5. ed. Rio de Janeiro: Forense, 2015.

TEPEDINO, Ricardo. Seção VI. Da falência requerida pelo próprio devedor. In.: ABRÃO, Carlos Henrique; TOLEDO, Paulo F. C. Salles (Coord.). Comentários à Lei de recuperação de empresas e falência. 6. ed.. rev., atual. e ampl. - São Paulo: Saraiva, 2016.

VALLE, Christino Almeida do. Teoria e prática da ação revocatória. Rio de Janeiro: AIDE Editora, 1987.

VALVERDE, Trajano de Miranda. Comentários à Lei de Falências. v. I. 4. ed.. Rio de Janeiro: Editora Revista Forense, 1999. 